\title{
A Third Sector-Led Economic Model: Scopes of Islamic Entrepreneurship
}

\author{
Rafiqul Islam Molla \\ Academic advisor \\ International Islamic University Chittagong, Bangladesh \\ Email: rimolla@gmail.com
}

Md. Mahmudul Alam*

PhD Student

Institute for Environment and Development (LESTARI)

National University of Malaysia

Selangor, Malaysia

E-mail: rony000@gmail.com

* Corresponding author

\section{Citation Reference:}

Molla, R.I., and Alam, M.M. 2013. A Third Sector-Led Economic Model: Scopes for Islamic Entrepreneurship, American Journal of Islamic Social Sciences, Vol. 30(1), pp. 73-91. (online) https://www.ajiss.org/index.php/ajiss/article/view/311 (ISSN: 0887-7653; Publisher: International Institute of Islamic Thought (IIIT))

This is a pre-publication copy.

The published article is copyrighted by the publisher of the journal. 


\title{
A Third Sector-Led Economic Model: Scopes of Islamic Entrepreneurship
}

\author{
Rafiqul Islam Molla ${ }^{a}$ \\ Md. Mahmudul Alam ${ }^{b}$
}

\begin{abstract}
Private (first sector) and public (second sector) sector economics, both individually and jointly, have failed to ensure the wellbeing of human societies on the national and global levels. In response, social enterprise (third sector) economics, which features cooperatives and not-for-profit social enterprises, foundations ( $a w q \bar{a} f$ ), and similar undertakings, has emerged as a make-up strategy in an attempt to counter the deficiencies of the market-state economic model. However, there is a strongly felt belief that the third sector needs to be broadened and mainstreamed in order to include both not-for-profit and for-profit businesses blended with social justice (via provision of such social welfare programs as corporate social responsibility) so that they can play a major role in poverty alleviation and economic growth.

Islamic entrepreneurship, which is basically a community-centric mode of business initiative, is an antidote to the problem of intolerable economic and social dualism, a natural strategy against all forms of capitalist exploitation and attempts to control a nation's resources. Moreover, it is the natural model for solving economic inequity, wealth concentration, and social divides. Based on its potential and using examples from Bangladesh and Malaysia, we present the Islamic style of entrepreneurship. We contend that this particular style is the most efficient and desirable one for effectively widening and mainstreaming community-centric third sector economics so that it can ensure development with equity and social justice especially in developing countries.
\end{abstract}

\section{Introduction}

During the sixteenth century in Christian Europe, leading Puritan and Protestant reformers declared wealth to be a gift from God, thereby freeing the pursuit of wealth from social and religious stigma, on the condition that the wealth acquired would be used for righteous purposes. This development led to unrestricted individualism, which soon opened the doors for wealth making and accumulation, as well as a nascent form of capitalism. European law and legal structures were accordingly designed to nurture this new trend, which formally grew up under Adam Smith (1723-90) and other classical economists and then blossomed and flourished under Alfred Marshall (1842-1924) and other neoclassical economists. Smith, the father of modern economics, defined it as the effective use of society's resources for humanity's wellbeing. Over the time, it grew and thrived for that very purpose. Its disciplinary development, however, was pursued through ideologically and operationally

a Rafiqul Islam Molla is the academic advisor at the International Islamic University Chittagong, Bangladesh. He is a former professor at North South University, Bangladesh, and a specialist in economics at the Multimedia University, Malaysia. He can be contacted at rimolla@gmail.com.

b Md. Mahmudul Alam is a doctoral student at the Institute for Environment and Development (LESTARI), the National University of Malaysia (UKM), and Research Coordinator of Bangladesh chapter at Islamic Online University. He can be reached at rony000@gmail.com. 
different dominant modes: the market (private sector) and the state (public sector) economic systems.

The private sector economy relies on methodological individualism and profit maximization on the assumption that individual benefits, when added together, will maximize society's benefits. It has two main features: (1) the individual's benefit is placed at the center (2) and it is based on free market competition, meaning that the "strongest takes it all" following the Darwinist social philosophy of "survival of the fittest." "The pervasive drive to accumulate capital and the ceaseless search for new technology and markets, the most vital attribute of capitalist market economics, necessitates the establishment of economic imperialism. Historically, this took the form of colonization. ${ }^{2}$ Gilpin refers to this phenomenon as the law of capitalist imperialism: As these economies mature and their capital accumulation and profit rates fall, they are compelled to seize colonies and create dependencies to serve as markets for their outputs and inputs, as well as for investment outlets. ${ }^{3}$

Joan Rabinson observes that contemporary Third World countries are drawn into the capitalist world market under regimes of formal and informal colonialism, as appendages of the metropolitan/industrialized nations, to supply raw materials and exotic commodities for their industries. ${ }^{4}$ Noam Chomsky, Srachaet Charaschanya \& Arayada Arayawuth, Andreas von Buelow, the Chronology of American State Terrorism, and others have analyzed and explained how American state terrorism has actively used economic imperialism to control the world's industrial raw materials, especially oil, natural gas, exotic resources and markets, for their industrial and war materials. Chomsky, along with Charaschanya and Arayawuth, report that so far the United States is the only country to be condemned by the World Court for international terrorism (viz., President Ronald Reagan's undeclared war on Sandinistaruled Nicaragua during the 1980s). ${ }^{5}$ Von Buelow reports that in the mid-1990s Zbigniew Brzezinski campaigned for the United States to have sole right to all of the world's raw materials, especially crude oil and natural gas. The Chronology of American State Terrorism provides a historical record of these activities worldwide, ${ }^{6}$ and William Blum gives an account of the weapons of American terrorism. ${ }^{7}$

The political economy of the culture of profit maximizing market economics is founded upon the spirit and principle of Darwinist social philosophy and tailored to create the unjust extreme economic and social imbalances required for capital accumulation. This worldview eventually gave birth to oppression via Europe's colonization of territories and nations, a reality that now continues through American policies and American-led terrorism for occupation, domination, and control of world's natural resources.

Public sector economics, on the other hand, puts society methodologically at the center and relies on the philosophy that society's benefit is the summation of all individual benefits. Under Marshall, during the last quarter of the nineteenth century economics developed to the point that, especially in terms of mathematical and technical proficiency, it was recognized as a science and became known as the "darling queen" of the social sciences. ${ }^{8}$ At that time the market, which consisted of competing for-profit firms, was conceived as being the sole agent for the efficient organization and management of the economy, a set up by which the community could grow and ensure its wellbeing. By the beginning of the twentieth century, people realized that the market alone could not be trusted to ensure community wellbeing. This led to the idea of the state's necessary involvement and participation side by side with the market - the market would produce and supply mainly the private goods, whereas the state would produce and supply primarily the public and collective goods. 
As this market-state mixed economy model was considered necessary to ensure the community's wellbeing at national and global levels, it became increasingly accepted by academicians, professionals, and policymakers. But its serious shortcomings surfaced when the income inequalities within and among nations continued to increase. The principle of profit maximization without regard for social justice led private sector enterprises to exploit others and concentrate wealth in the hands of the small group of capital-owning private sector business enterprises. The state's inherent inability to handle economic/business operations resulted in gross inefficiency and economic losses, as well as vulnerable public sector enterprises. The significantly increasing income inequalities eventually became so obvious and embarrassing that the 2001 report put out by the UN High-Level Panel on Financing for Development lamented:

Sadly, increasing polarization between the haves and have-nots has become a feature of our world. Reversing this shameful trend is the preeminent moral and humanitarian challenge of our age. ${ }^{9}$

The World Development Indicator 2007 reported that in $200584 \%$ of world's population received only $46 \%$ of the world's income. ${ }^{10}$ The Gini coefficients of the world's income and wealth distributions are 0.619-0.68 and 0.892, respectively, which signify an extremely high inequality level of global income and wealth distribution. ${ }^{11}$ The richest $1 \%$ of adults own $40 \%$ of the world's wealth, and $2 \%$ own more than half of the world's household wealth. Even the wealth inequality within nations is too high: the wealth Gini of Japan is 0.55 , and the wealth Gini of the United States is about 0.8 .

Moreover, this model has failed to eliminate the most acute forms of poverty in many countries. The excessive emphasis placed on self-interested and competitive behavior has weakened feelings of social unity, and thus the social bonds among people, as well as

diminished relations built on trust and cooperative behavior. Such negative developments heighten people's sense of vulnerability and fears for the future. ${ }^{12}$

The increased economic growth has not been matched by increased wellbeing and happiness. Therefore, both private and public sector economics have been found seriously inadequate to the task of ensuring the wellbeing of societies as well as nations. Various attempts made to remedy the shortcomings of this model, such as reducing the size of the public sector via transferring many public sector enterprises to the private sector, known as privatization, did not yield the expected results. This indicates how difficult it is to obtain socially responsible behavior from agents concerned only with maximizing their self-interest.

\section{The Emergence of Third Sector Economics}

The basic goals of economics are allocative efficiency, distributive efficiency, social justice, and balanced development for all. Distributive efficiency, a value-driven function, includes the universally desired socioeconomic goals of need fulfillment, full employment, an optimum rate of economic growth, an equitable distribution of income and wealth, economic stability, and ecological balance. All of these are generally considered indispensable for actualizing human wellbeing. But when driven by profit maximization, mainstream market economics is highly deficient and unable to meet these normative goals. Due to its secularist worldview, characterized by a materialist and social Darwinist outlook, conventional economics fails to specify the necessity of individual behavior to serve the public interest. ${ }^{13}$ 
What is required now, therefore, is a new paradigm that can achieve this purpose and goal in the most effective manner possible. ${ }^{14} \mathrm{~A}$ new balance must be found among markets, governments, and other institutions (e.g., not-for-profits and cooperatives) in order to build a plural economic system with several pillars. ${ }^{15}$ Scholars also see cooperatives and social enterprises as better able to coordinate collective action, promote collaboration, enhance trust, and increase freedoms.

Responding to such a situation, various non-conventional approaches (e.g., cooperatives and social enterprises, foundations, and other non-profit institutions) that make up the third sector economy were moved and promoted as being more capable of ensuring humanity's wellbeing. ${ }^{16}$ This approach seeks to achieve this by mobilizing and demanding that entrepreneurs direct their work toward benefiting society by making social benefit the prime mover of their entrepreneurialism. Initially, it emerged as a make up and defensive strategy of the market-state model to meet the minimum unmet requirements in those sectors failed by both the market and the state. It is typically conceived of as an economic model comprising the not-for-profit, non-government, and other organizational bodies that can provide personal and collective services more efficiently than either for-profit or public organizations. Cooperatives and social enterprises are the two main movements of third sector economics.

A cooperative can be defined as a voluntary organization (e.g., a farm or a firm) that is owned and managed jointly by its members for a common goal and that shares benefits among themselves. ${ }^{17}$ This jointly owned commercial enterprise, usually organized by farmers or consumers, produces and distributes goods and services and is run for the benefit of its owners. It follows the (modified) Rochdale principles: open and voluntary membership, democratic governance, limited return on equity, surplus belongs to members, education of members and the public in cooperative principles, cooperation among cooperatives, and concern for the community. ${ }^{18}$ However, the key element is serving the interests and benefits of its members.

While a typical cooperative regards serving the community as only incidental, a social enterprise is a "social mission driven" business organization. Filipe Santos defines it as an activity that focuses primarily on value creation rather than value appropriation. Social enterprises include both non-profit and for-profit enterprises that apply a market-based business approach in their operations in order to achieve social objectives. ${ }^{19}$ According to Muhammad Yunus, the key element of a social business is that investors receive only their original investment, for there is no additional dividend or capital return. ${ }^{20}$ These are businesslike operations, but their main concern is not business; rather it is to satisfy a social need while being economically sustainable. Despite what such an entity may be called, it may be described as any for-profit or non-profit organization that applies capitalistic strategies to achieve philanthropic goals without any ulterior motive. It can, therefore, be described as "doing charity by doing trade," rather than "doing charity while doing trade."

Some recent theoretical developments have helped strengthen the academic and analytical arguments for the third sector economics. ${ }^{21}$ First, new theories concerning it have shifted away from viewing the firm as an entity centered on profit maximization to one of working as a coordinator with the goal of solving society's problems via the production of goods or services. This new conception broadens the firm's role by envisaging how it can be used to produce public and collective-interest goods as well. 
Second, new contributions of the Behaviorist School and experimental economics to the analysis of individual behaviors question the hypothesis that every human action and, in particular, every economic action is governed exclusively by self-interest. The Behaviorist School maintains that human actions spring from a mix of motivations (e.g., intrinsic, extrinsic, self, others) and are influenced by a general ethical factor of inclination to help each other and uphold justice and equity. These theoretical developments clearly point to the truth that human beings are fundamentally ethical social beings and, secondarily, economic beings. In fact, this is the message of Islam and all other revealed religions.

These two theoretical developments have helped explain why the objective of an enterprise is, or can be, to solve a collective problem, for these new theories provide the rationale for third sector economics. Thus, and especially during the last several decades, the dominant models' inability to respond to the people's numerous needs has, among other things, allowed the development and growth of cooperative and social enterprises created by citizens and civic movements. Under these circumstances, the third sector economy is now seen as a viable and needed economic model that can ensure the realization of economic's fundamental goal: humanity's wellbeing at the national and global levels.

\section{Limitations}

Unfortunately, right from the beginning these movements' conceptual, structural, and functional basis revealed that they were meant and designed as special programs to deal with primarily with the economy's peripheral areas: poverty alleviation, rural development, and agricultural development. This gave the two other models a free hand to operate in all of the economy's dominant and growth-generating sectors. Moreover, there was a widespread belief that third sector economics were best suited to providing personal and community care services. This reflects the tendency of even donors and international agencies to promote cooperatives and social enterprises only as tools to reduce poverty and generate employment. $^{22}$ As a result, third sector economics remained outside the mainstream economy, acquired no dominant role, and did not gain the necessary recognition and respectability.

Several large and successful social enterprises (SEs) have appeared in Asia, such as the Grameen Bank, the Bangladesh Rural Advancement Committee (BRAC), and the Population and Community Development Association (PDA). All of them receive extensive government and donor support. The other SEs, which are small or mid-sized, are nonetheless having some success at realizing the socioeconomic goals in both the for-profit and not-for-profit sectors. ${ }^{23}$ But despite their invaluable contributions to bridging social divides and achieving the community's wellbeing, this sector is not receiving the expected attention and recognition that it needs to develop and expand its reputation as a more effective dominant economic model for achieving balanced and sustainable development. Rather, it is being treated as a peripheral activity, one that has been sidelined in managing the national economic sphere. If it is to play its envisaged and expected role as the world's new dominant and leading economic system, it must be broadened and mainstreamed.

\section{Affinity with the Islamic Economic System}

Third sector economics and Islamic economics seek to achieve similar objectives: humanity's collective benefit, balanced and just economic development, the equitable distribution of 
income and wealth, the narrowing of income gaps, closer understanding and trust among nations and societies, and an increased quality and standard of living for everyone.

Islam's commitment to comradeship and justice makes the wellbeing (falāh) of all human beings its principal goal. Given that this is achieved by the balanced realization of humanity's material and spiritual needs, ${ }^{24}$ the mere maximization of total output cannot be the goal of a Muslim society. The missing element here would be the simultaneous effort to ensure the person's spiritual health at the inner core of human consciousness and interactions. Economic development can be considered as realized only after everyone's needs have been met, the generated income and wealth have been distributed equitably, and full employment and environmental protection have become realities.

Islamic economics is founded on the principle of goal realization rather than profit maximization, for ethics dominate economics. This "ethical factor" fundamentally sets the Islamic system apart from all other economic systems, ${ }^{25}$ because ethics epitomize a society's common values and determines its members' preference structures. The separation of economics from ethics has no place in this system, for ethics set the tone for economics and thus devises rules of economic behavior based upon Islam's ethical norms. The result is a value-driven system that exists fundamentally to meet the ethically determined and demanded normative goals for the society's wellbeing: a just and balanced social system - "a social environment that brings a sense of community and fellowship in human relationships" - that demands the official recognition of justice, human dignity, and compatibility among humanity, technology, and the natural environment. Such a social environment requires far more than economic growth and prosperity, than the so-called efficient allocation of resources. Therefore, this system supports the view of economic development described by Myrdal as an upward movement of the entire social system, or simply growth plus change in the redistribution of income in favor of the lower income groups so that economic dualism is avoided.

In Islam, however, economic development is viewed as only one element of social wellbeing. It is important, but only as a contributor to the spiritual, material, and social uplift of human beings. Thus entrepreneurship is geared toward ensuring an expansion of production that benefits and improves the everyone's quality of life, thereby allowing them to enjoy conveniences and a moderate amount of luxuries (but avoiding extravagance). ${ }^{26}$ As long as the entrepreneurs' focus and prime mover is community (as opposed to individual) benefit, third sector and Islamic economics have a great deal in common.

\section{Potentials of the Third Sector and the Call for Its Restructuring}

With its community-centric conceptual base and social justice-driven motivation, the third sector stands as the superior economic model for goal realization. In addition to having the best potential to manage the economy most effectively with regard to having a human face and heart, it is the best method to attain sustainable growth and equitable development for everyone.

Unfortunately, as noted earlier, third sector economics has remained, both conceptually and operationally, largely confined at the economy's peripheral areas and serves only to fill gaps. Typically, its field of activity comprises the non-government and not-for-profit bodies, of which cooperatives and social enterprises are its two main arms. This not-for-profit narrow base has seriously limited its growth and expansion, as well as its entry into the growth- 
yielding and more challenging industrial sectors of the mainstream economy. Given that profit seeking and profit making are the legitimate right of entrepreneurs, no enterprise can survive and remain in business it if does not generate a suitable amount of profit. This is why the normal profit, without which the business would fail, is calculated as a part of economic cost. Therefore, third sector economics should not remain confined to not-for-profit activities; rather, its spirit and essence demand the widening of its sphere and domain of operations through both not-for-profit and for-profit modes of operation.

Many people expected that third sector economics would become another dominant model, one that works not only for poverty alleviation, but also for enhancing economic growth in order to bridge the economic and social divides. Accordingly, in recent decades attention has been given to widening the scope of its goals and objectives, not to mention expanding its spheres of operations. Therefore, it needs to expand its conceptual base, domain of operations, and types of enterprises and objectives, it should expand beyond cooperatives and social businesses to for-profit businesses to inject its provisions for social justice into the economic mainstream.

Neither a not-for-profit nor a profit maximizing objective alone can serve as the natural theme of general or mainstream economic activities. Rather, such behaviors could be special cases for special circumstances. Perhaps a mixture of the two could somehow serve as the rules of behavior for business entrepreneurs. In his theory of moral sentiment, Smith emphasized that people are endowed with two instincts: self-interest and sympathy (viz., feelings for others), and that the latter constantly moderates the former so that the other person's interests are protected. Therefore, the entrepreneur's natural behavior is expected to be earning a profit, but within the framework of social justice. Maximizing or seeking excessive profit (profiteering) without due regard for social wellbeing is not a legitimate right.

The restructuring of the third sector economics should benefit from this attribute of human nature and include the following additional types of enterprises in its list: (1) profit-driven businesses that contain some social benefit-driven operations, (2) public-private partnership (PPP) enterprises that feature social benefit as a control factor, (3) all Islamic business enterprises with ethics and social benefit as control factors, and (4) cooperatives that benefit their members but also have some operations devoted to community benefits.

Accordingly, it should be restructured to include both not-for-profit enterprises and for- profit "businesses blended with social justice" so that it may ultimately become a large and dominant economic model, one that is comparable with the market-based first sector as regards its share and control of the economy. With this expansion and restructuring, the third sector will be strong enough to significantly influence the first sector to moderate and blend its profit-maximizing behavior with equity and social justice. The result of this new arrangement will be the best and most desirable economic model for ensuring balanced and sustainable growth. Along with this will come an equitable distribution of income and wealth, as well as the realization of economics' ultimate goal: the wellbeing of human society at national and global levels.

This restructuring will require a regulatory provision of the registration for enterprises as third sector enterprises specifying the plan of action they have devised to meet their commitment and accountability to social justice. Since profit maximization is not their basic 
or only reward, there should be regulatory provisions for rewarding them as a category by a socially respected trademark, award of social titles as recognition to the successful enterprises and entrepreneurs, special financial and other supports in the event of a temporary financial crisis or genuine business failure, punishment through withdrawal of the trademark, social and economic privileges, and so on in case of willful negligence to their stated commitment. This new regulation may conveniently accommodate the earlier regulations for NGOs, cooperatives, foundations, and similar organizations.

\section{The Role of Entrepreneurship in Economic Growth and Development}

As entrepreneurs are the economy's initiators and drivers, the importance of entrepreneurship cannot be overestimated in accelerating economic growth and development. Entrepreneurs undertake innovations and initiate efforts to transform innovations into economic goods. In business terms, the most obvious form of entrepreneurship is a "startup company," usually a person (or enterprise) who pioneers change. Innovative entrepreneurs who are willing to take risks are an essential human resource in any economy. They are very few, particularly in the developing countries.

A more comprehensive and descriptive business definition could be that entrepreneurs organize, manage, and assume the risks of a business. They see problems as opportunities and, accordingly, identify solutions and find customers who are ready to pay for such products/solutions. According to Joseph Schumpeter, such people are willing and able to convert a new idea or invention into a successful innovation. ${ }^{27}$ They work for change through "the gale of creative destruction," the process of changing the old to the new. This innovation-driven process of creative destruction is largely responsible for the dynamism of industrial advancement and long-term economic growth. Entrepreneurship, therefore, is an indispensable function of economic growth in its continuous quest for social wellbeing and progress.

\section{The Required Qualities of Entrepreneurs}

Entrepreneurship is more than just starting a business or two; it is about having the proper attitude and the drive to succeed. Entrepreneurial abilities and qualities, which are very scarce and valuable, are needed to improve upon that which already exists and to create new goods and services.

\section{For Conventional Economics}

Various western scholars have summarized the common personal qualities of successful entrepreneurs for market economics as follows: the inner drive to succeed and being very ambitious; having a strong belief in themselves and an assertive personality; creative and searching for new ideas and innovations; open to change and therefore dynamic in nature; competitive by nature; highly motivated and energetic with an abundance of self-motivation; able to accept constructive criticism and rejection; and having a positive attitude. But the most essential ones, at least from the perspective of community wellbeing (viz., motives to serve the social goals and values, commitment to ethics and religious values) are not present in this list. These are, in fact, the missing items of personal qualities that differentiate the entrepreneurs of market economics from the Islamic entrepreneurs and, similarly, the entrepreneurs for the third sector economics. 


\section{For Islamic Economics}

Islam regards entrepreneurship as essential and indispensable for the progress of human civilization, as well as for effectively exploring and exploiting existing and potential resources to beneit humanity. In Islam, engaging in business is to perform a duty that is obligatory upon the community (fard kifāyah) as opposed to the individual. This obligatory duty must be performed by at least one or some on behalf of the entire community. To have no entrepreneur in a community is regarded as sinful for the entire community. This is how seriously Islam perceives and encourages entrepreneurship, and why it has made this activity a societal, as opposed to a personal, obligation. Those who seek to fulfill it must seek to pioneer continual change through innovations in the economic environment, first and foremost, for society's benefit. Profits are incidental.

Islam endorses entrepreneurship, regardless of whether it is driven by opportunity or necessity, as long as it is based upon a solid moral and ethical grounds and conforms to Islam's code of conduct. Entrepreneurship in western societies is mainly driven by the prospect of material rewards. Islam has nothing against this goal; however, those involved in this sphere must realize that every business undertaking is a form of religious duty intended first to please Allah, second to satisfy society's needs, and third to generate a reasonable income for the owners. Islamic entrepreneurship is not against seeking a reasonable profit, but it does put ethical consideration and community interest first. Given that Islam aspires to create high quality entrepreneurs and productive Islamic entrepreneurship, Muslim entrepreneurs are permitted and encouraged to be involved only in morally accepted and socially desirable productive business activities. Therefore, all activities associated with alcohol, drugs, usury, prostitution, gambling, and highly speculative business behavior are strictly prohibited, despite the possibility of their economic viability.

Islam views entrepreneurship from a larger perspective, and thus entrepreneurs assume an altruistic role that goes beyond satisfying their immediate needs and personal interests. Given this, the pursuit of self-interest and self-centered wealth creation are not the primary motives. Altruistic motives override personal considerations, due to the conviction that one's selfinterest will be realized as a natural outcome while pursuing society's common welfare. The entrepreneurs' personal motives for starting their businesses are considered important factors that explain the status and direction of entrepreneurship in a country. Their ability to orchestrate and lead the economic transformation, as well as to carry out the needed fundamental cultural and socio-economic changes, depends greatly upon the entrepreneurial motives of the new business founders.

Besides being holistic in approach, Islamic entrepreneurship insists that entrepreneurs must first be religious people and motivated by success in this world and the next. Islam views entrepreneurial success as not confined to merely the bottom-line principle of earning profit and material wealth. In fact, entrepreneurship is considered an integral part of Islam, which encourages its members to engage in business as part of doing good deeds. Muslim entrepreneurs, just like other Muslims, are considered God's agent and thus are guided by the ethics and values prescribed by the Qur'an and the prophetic Sunnah.

\section{The Scope of Islamic Entrepreneurship}

Actualizing this needed expansion for the third sector model's desired success requires the right kind of entrepreneurship to guide and lead the economy toward development with social 
justice. As noted earlier, entrepreneurs in the market-led economy are motivated and driven by profit maximization. Community wellbeing through such provisions like corporate social responsibility (CSR) is only a residual consideration. CSR is used mostly as a public relations instrument and a marketing strategy, again with the motive of gaining market control for maximizing corporate profits. ${ }^{28}$ They remain engaged in serving the need fulfillments of the haves while ignoring those of the have-nots. This kind of entrepreneurship and profit maximizing market economics harm society and have brought about all sorts of exploitation and oppression. Islam addresses such issues by calling upon people to resist it and work constantly for social betterment and development for it is the duty of all Muslims to oppose oppression. This has given birth to revolutions, resurgences, and resistance movements against all types of oppression and oppressors.

Entrepreneurs in the Islamic mold are guided by Islamic ethics in their search for the best way to serve humanity. For them, the motivating factors are human wellbeing and God's pleasure. The unique ethical and motivational structure of Islamic entrepreneurship gives first priority to community considerations, and only then to individual benefits. It locates the community as the primary stakeholder of the output of any entrepreneurial action. Islamic entrepreneurs fit very well into this proposed third sector economic model. Applying the principles of Islamic entrepreneurship, this sector can grow, expand, and begin to attract large numbers of enterprises that are currently operating in the mainstream and growth sectors of the economy. Only then it can upgrade itself to being on the same footing as the first sector so that it can effectively fulfill its role of ensuring sustainable growth with equity and social justice at the national and global levels.

However, many entrepreneurs may not be so committed to Islamic convictions and spirituality. This is particularly true among non-Muslims, who obviously cannot be expected to conform fully to the particular Islamic norms discussed above. Under these circumstances, any business that falls short of fully conforming to these norms but does conform reasonably well to all of its material aspects and community-centric spirit, may be called an Islamic-style business. This is especially the case if the following elements are based on Islamic ethics: output maximization, profit maximization, employee benefits, and so on. Profits for the equity holders and benefits for employees are seen as residual matters. Therefore, especially for the developing countries, the third sector economics model may be the most appropriate for achieving sustainable development with equity.

\section{Bangladesh and Malaysia}

\section{Islami Bank Bangladesh Limited $^{29}$}

One of the Islami Bank Bangladesh Limited's distinguishing features is that its overall activities are directed toward the society's overall welfare. Its firm commitment to uplift and emancipate the country's poor people has resulted in the creation of a separate fund, the Islamic Bank Foundation, to carry out this social responsibility through

i. Income-generating self-employment programs (e.g., rickshaws, sewing, poultry keeping, rural health work, milch cow/goat rearing, and small trade) to provide access to the required finance and other inputs necessary. 
ii. Education programs to improve the country's educational scenario by supporting Forquania Maktab, scholarships/grants to poor and meritorious students, and financial support to educational institutions.

iii. Health and medicare programs to extend health, medicare, and sanitation facilities to the urban and rural areas (e.g., establishing medical centers, supporting charitable dispensaries, lump-sum help for medical treatment, tube well installation, and sanitary latrine construction).

iv. Humanitarian help, relief, and rehabilitation programs for the poor and needy.

v. Dawah programs, such as working with prisoners to reform their morals.

vi. Monoram (beautiful) crafts and fashion programs that will allow distressed women find sales outlets for home-made garments, handicrafts, and other items. The other objective is to develop clothing that conforms to Islamic norms and that compare well with contemporary fashions.

vii. Service centers to be constructed in coastal areas, river deltas, and off-shore islands that can be used for social development as well as to provide shelters during natural disasters. Two such service centers have already been established in Noakhali and Manikgonj.

viii. International schools and colleges that will transform local youths into human capital with relevant technical skills. So far, it has established two technical institutes in Dhaka and one in Bogra that offer training in computer, secretarial science, driving, electrical, refrigeration and air conditioning, radio and television, and tailoring and garments.

Sheba Polly ${ }^{30}$

Sheba Polly Bhadughor, in Bangladesh, represents another type of Islamic style third sector entrepreneurship: a cost-based charity established by local initiative to serve community members under the motto of "service according to need and payment according to ability." This field-level integrated rural development program provides six categories of development aids: health aid (health first, health for all), employment generation aid (access to work and earning for a living), educational and religious aid (access to basic education as well as religious knowledge and practices), legal aid (access to justice), socio-cultural aid (the right to promote one's culture and live with social dignity), and agricultural aid (every farmer must have access to modern agricultural technology). It also tries to motivate community members to commit themselves to social services based on the Islamic concept that "serving humanity is serving religion." It has a ten-bed hospital, a nursing training school, a medical technology training institute, a handicraft institute, a youth club, and a services center.

\section{Johor Corporation (JCorp) $)^{31}$}

The Malaysian state of Johor's government's investment agency, Johor Corporation (JCorp), is an example of successful Islamic entrepreneurship. By creating a corporate waqf, WANCorp, it has successfully initiated a new way of doing business under the banner of "Business Jihad," an alternative to the purely shareholder-centric business-driven economic model. Its mission and slogan, "Building wealth for all with Islamic entrepreneurship," is based on the waqf. According to Islamic law, a waqf is a permanent endowment or trust, customarily of real estate, in which the proceeds are spent for purposes designated by the benefactor: to fund such charitable institutions as schools, orphanages, hospitals, and mosques. This newly created corporate waqf, a legally recognized community-owned corporation that continues in perpetuity, produces useful goods and services for society. 
Profits are reinvested or fund community interests in charitable or social causes to bridge the social divides. It is more or less like a "social business." Proponents claim that this approach largely adheres to the nature and character of Islamic entrepreneurship, for its ultimate goals are community and social justice. This staunchly business-like initiative of an Islamic-style third sector entrepreneurship has initiated a shift from the conventional to a communitycentric business concept.

\section{Conclusions}

The market-state economic model has failed to ensure the wellbeing of people and society. Thus the third sector economic model, comprising cooperatives and community-centric notfor-profit social enterprises, emerged to meet these sectors' minimum unmet requirements. However, a broadly based third sector economic model with both not-for-profit and for-profit businesses blended with social justice needs to go mainstream so that it can help alleviate poverty and bridge the existing economic and social divides through economic growth. Islamic entrepreneurship, a community-centric mode of business, is a natural model for solving the problems of economic inequity, the concentration of wealth, and social divides.

Therefore, this study finds that the Islamic mode of entrepreneurship is the most suitable and effective approach to mainstreaming third sector economies, primarily in developing countries. Nations and societies that are interested in expanding, developing, and mainstreaming their third sector economies may profitably promote this model, which approves of seeking a reasonable profit but puts ethical considerations and community interest above everything else. There is, therefore, a need for credible research in the field of a community-centric economic model.

\section{Endnotes}

${ }^{1}$ Rafiqul I. Molla, Md. M. Alam, and Md. W. Murad, "The Deceptive Game of Today's Capitalist Globalization: Evidence from Malaysia's Experience," European Journal of East Asian Studies $10, \quad$ no. 2011$)$ (2011 http://www.ingentaconnect.com/content/brill/eeas/2011/00000010/00000002/art00004 (accessed on 24 June 2012).

${ }^{2}$ Robert L. Heilbroner and William Milberg, The Making of Economic Society, 12th ed. (New Jersey: Pearson Education, Inc,), 41 and 208.

3 Robert Gilpin, The Political Economy of International Relations (Princeton: Princeton University Press, 1987), 39; David N. Balaam and Michael Veseth, Introduction to International Political Economy, 4th ed. (Upper Saddle River, NJ: Pearson Education, Inc., 2008), 70.

4 Joan Rabinson, "Trade in Primary Commodities," in International Political Economy, ed. Jeffrey A. Frieden and David A. Lake, 2d ed. (New York: St Martin's, 1991), 376; Balaam and Veseth, Introduction, 63.

${ }^{5}$ Noam Chomsky interviewed by David Barsamian, "The United States is a Leading Terrorist State," Monthly Review 53, no. 6. http://monthlyreview.org/2001/11/01/the-united-states-isa-leading-terrst-state (accessed on 24 June 2012).

6 The Berlin Tagesspiegel Daily, "Former Top German Minister Rejects Official Story of 9/11 Attacks," Jan 13, 2002. (online) www.ratical.org/ratville/CAH/VonBuelow.html (accessed on 24 June 2012); Chronology of American State Terrorism, accessed June 24, 2012, hateusa.narod.ru/terror.htm. 
7 William Blum, "The Weapons of American Terrorism," Rogue State: A Guide to the World's Only Superpower. www.rense.com/general14/wap.htm (accessed on 24 June 2012).

${ }^{8}$ Rafiq I. Molla. "Faith-based Intellectualism in Contemoporary Economic Thought: A Desirable Come-back Phenomenon," European Journal of Scientific Research 1, no 2 (205): 77-86.

${ }^{9}$ Report of the High-Level Panel on Financing for Development, United Nations, 2001. www.un.org/reports/financing/full_report.pdf (accessed on 24 June 2012).

${ }^{10}$ Michael P. Todaro and Stephen C. Smith, Economic Development (New York: AddisonWesley, 2009), 56.

${ }^{11}$ Evan Hillebrand, Poverty, Growth, and Inequality Over the Next 50 Years, Expert Meeting on How to Feed the World in 2050, FAO, 24-26 June 2009, 11. ftp://ftp.fao.org/docrep/fao/012/ak968e/ak968e00.pdf (accessed on 24 June 2012); Bob Sutcliffe, Postscript to the article "World inequality and globalization," Oxford Review of Economic Policy (spring 2004), siteresources. worldbank.org/INTDECINEQ/.../PSBSutcliffe.pdf (accessed on 24 June 2012); James B. Davies, Susanna Sandstrom, Anthony Shorrocks, and Edward N. Wolff, The World Distribution of Household Wealth (Finland: World Institute for Development Economics Research, United Nations University, December 2006, 26). www.iariw.org/papers/2006/davies.pdf (accessed on 24 June 2012).

${ }^{12}$ Carlo Borzaga, Sara Depedri, and Ermanno C. Tortia, The Role of Cooperative and Social Enterprises: A Multifaceted Approach for an Economic Pluralism. Euricse Working Papers $\mathrm{N}$. 000/09. http://www.euricse.eu/sites/euricse.eu/files/db_uploads/documents/1269529638_n360.pdf (accessed on 24 June 2011).

${ }^{13}$ For conventional economics, ethics and morality is not based on humanity. For example, economic agents measure and judge what is right/wrong and good/bad according to "more is better" and "survival of the fittest." Thus producers are motivated to provide those goods and services that earn them the highest profit, as opposed to meeting society's needs, regardless of their effect. In such a situation, as Samuelson noted, producers may not be motivated to produce milk essential for babies of low income families if they cannot pay a high price for it.

See Paul A. Samuelson, Economics: An Introductory Analysis, 7th ed. (New York: McGrawHill Book Company, 1967), 44. They would rather produce dog and cat food if high income families will pay higher prices for it. Unfortunately, such a negative reality is a matter of indifference for the ethics of market economics, because such ethics provide no moral guidance to this system's economic agents. See the European Research Institute on Cooperative and Social Enterprises, Philosophy: Guiding Principles for the Study of Cooperative and Social Enterprises. http://www.euricse.eu/sites/euricse.eu/files/db_uploads/documents/1265989136_n334.pdf (accessed on 24 June 2011); UNDP, Social Enterprise: A New Model for Poverty Reduction and Employment Generation. An Examination of the Concept and Practice in Europe and the Commonwealth of Independent States. http://europeandcis.undp.org/poverty/show/2F171313-

F203-1EE9-B687694A1F8C9AEC (accessed on 20 January 2011).

${ }^{14}$ Mark Blaug, The Methodology of Economics (Cambridge, NY: Cambridge University Press, 1980), 33; Thomas Balogh, The Irrelevance of Conventional Economics (London: Weidenfeld \& Nicolson, 1982), 109; Umer Chapra, What Is Islam Economics? (Jeddah: IRTI, Islamic Development Bank, 1996), 24. 
15 Joseph Stiglitz, "Moving Beyond Market Fundamentalism to a More Balanced Economy," Annals of Public and Cooperative Economics 80, no. 3 (2009): 345-60.

${ }^{16}$ Ibid., 345-60.

17 International Co-operative Alliance, "Co-operative Identity, Values \& Principles" (accessed on 24 June 2012), http://2012.coop/en/what-co-op/co-operative-identity-valuesprinciples.

${ }^{18}$ Ibid.

${ }^{19}$ Filipe M. Santos, A Positive Theory of Social Entrepreneurship. INSEAD working paper. http://www.insead.edu/facultyresearch/centres/social_entrepreneurship/research_resources/ documents/2009-23.pdf (accessed on 24 June 2012).

20 Muhammad Yunus, Social Business, 2007, (accessed on 24 June 2012), http://www.muhammadyunus.org/Social-Business/social-business.

21 See European Research Institute on Cooperative and Social Enterprises, Philosophy: Guiding Principles.

${ }^{22}$ See UNDP, Social Enterprise: A New Model.

${ }^{23}$ Durreen Shahnaz and Patricia Shu Ming Tan, Social Enterprise in Asia: Context and Opportunities. Lee Kuan Yew School of Public Policy Research Paper No.LKYSPP09-018CAG006, 2009. http://www.asiaiix.com/wp-content/uploads/2010/03/Social-Enterprise-inAsia-Context-and-Opportunities3.pdf (accessed on 24 June 2011).

${ }^{24}$ Umer Chapra, Islam and Economic Development. Islamization of Knowledge - 14, (The International Institute of Islamic Thought and Islamic Research Institute: Islamabad, 1993), 6-7.

http://www.irti.org/irj/go/km/docs/documents/IDBDevelopments/Internet/English/IRTI/CM /downloads/Distance_Learning_Files/ISLAM\%20AND\%20EOCNOMIC\%20DEVELOPM ENT.pdf (accessed on 24 June 2012).

${ }^{25}$ Syed Nawab Haider Naqvi, Ethics and Economics: An Islamic Synthesis (Markfield, UK: Islamic Foundation, 1981), 18.

${ }^{26}$ Rafiqul Islam Molla, A. R. Moten, S. A. Gusau, and A. A. Gwandu, Frontiers and Mechanics of Islamic Economics (Nigeria: University of Sokoto, 1988), 199-200.

${ }^{27}$ Joseph Schumpeter, Capitalism, Socialism, and Democracy, 3d ed. (New York: Harper and Row, 1950), 132.

${ }^{28}$ Corporate Watch Report 2006, What's Wrong With Corporate Social Responsibility?, http://www.corporatewatch.org/download.php?id=55 (accessed on 24 June 2012).

${ }^{29}$ Islami Bank Foundation. http://www.islamibankbd.com/foundation/index.php (accessed on 24 June 2011).

${ }^{30}$ Rafiqul Islam Molla, "Islam-based Grassroots Institutions for Sustainable Integrated Rural Development: The Case of Sheba Polly in Bangladesh," Journal of Business and Behavioral Sciences 17, no. 1 (2008): 36-42.

${ }^{31}$ Zazali Musa, Malaysia Can Promote Islamic Entrepreneurship, The Star Online, April 10, 2011.

http://biz.thestar.com.my/news/story.asp?sec=business\&file=/2010/4/10/business $/ 20100410$ 083304 (accessed on 24 June 2011). 